\title{
Editorial
}

\section{Immunological abnormalities in cystic fibrosis: chicken or egg?}

Cystic fibrosis (CF) is a disease characterised by malabsorption, chronic bronchopulmonary infection, and a high sweat sodium concentration. In 1938 about $80 \%$ of patients died within the first year of life $^{1}$ but now many are surviving into adult life, ${ }^{2-4}$ and are being transferred from the care of the paediatrician to that of the thoracic physician. This increased survival is probably accounted for by improved paediatric care, increased understanding of the importance of efficient postural drainage, and the advent of antibiotics. Patients with CF may develop either pulmonary infection in the neonatal period which persists throughout life or neonatal infection which may respond to treatment only to recur in adolescence. A few patients develop pulmonary infection for the first time in late adolescent or early adult life.

Once bronchopulmonary infection with a given organism is established in a patient with $C F$ it is often impossible to eradicate this organism. While antibiotics may improve the patient's clinical state, respiratory function tests, and chest radiograph for a period, most patients eventually die of overwhelming bronchopulmonary infection by pathogens which appear in the laboratory to be sensitive to the antibiotics with which the patient is being treated. This therefore gives rise to the question as to whether the immune defences of patients with CF may be defective.

In recent years new techniques have been developed to explore both quantitatively and qualitatively the various components of the immune response. These techniques have now been applied to the study of the immune response in cystic fibrosis.

\section{T cell system}

Fifty to sixty per cent of peripheral blood lymphocytes are thymus-dependent $T$ cells. They have antigen recognition sites on their surfaces and on stimulation they release lymphokines. These lymphokines have many actions including the activation of macrophages. $T$ cells will transform with phytohaemagglutinin, will help or suppress $\mathrm{B}$

Address for reprint requests: Dr ME Hodson, Cardiothoracic Institute, Brompton Hospital, Fulham Road, London SW3 6HP. cell functions, and can show cytotoxicity. Normal numbers and percentages of $T$ cells have been demonstrated in patients with CF. ${ }^{56}$ It seems that CF lymphocytes may respond normally to both phytohaemagglutinin and pokeweed mitogen in normal serum but the response is decreased in CF serum, ${ }^{7-9}$ suggesting a serum rather than a cellular defect.

Lymphocyte responses to stimulation by Pseudomonas aeruginosa have been shown to be inhibited in some patients with advanced pulmonary infection with this pathogen. ${ }^{10}$ Since pulmonary alveolar macrophages are activated by lymphokines, unresponsiveness of lymphocytes to Ps aeruginosa antigen might be expected to cause inefficient macrophage clearance of that organism. Cystic fibrosis leucocyte migration may be inhibited by both normal and CF lung and pancreatic extracts, suggesting that CF lymphocytes may be sensitised to these tissue antigens. ${ }^{11}$ Cystic fibrosis leucocyte migration to Aspergillus fumigatus and Ps aeruginosa is also significantly inhibited, and it is possible that pulmonary infiltrates in patients with these organisms may be in part a hypersensitivity reaction. Skin tests of delayed hypersensitivity are generally normal. ${ }^{12}$ Studies of lymphocyte cytotoxicity, mediator production, and $\mathrm{T}$ helper and suppressor cell functions in CF have not yet been reported.

\section{B cell system}

B cells comprise $20-30 \%$ of normal peripheral blood lymphocytes. When stimulated they transform into plasma cells and release antibody in the form of IgM, IgG, IgA, IgD, or IgE. Hypergammaglobulinaemia has been described frequently in patients with CF. ${ }^{13-17}$ IgG, IgM, and IgA may be abnormally raised in $30-50 \%$ of patients and this relates to a poor clinical condition. ${ }^{18}$ In contrast, a low IgG is found in about $20 \%$ of children under the age of 10 years, related to less advanced pulmonary disease, and it has been suggested that initially there may be a failure to recognise antigen when it crosses the gut or respiratory mucosa with a later hyperimmune response. ${ }^{19}$

In patients with cystic fibrosis there is a high incidence of severe bronchopulmonary infection 
without evidence of excessive susceptibility to generalised infections. The local immune defences of the respiratory tract have, therefore, been the subject of extensive investigation. In general IgA, secretory piece and IgA-secreting cells have been shown to be present or increased in patients with $\mathrm{CF}$ in saliva, bronchial mucosa, and jejunal mucosa. ${ }^{20-23}$ However, the finding of free secretory components of IgA in the serum of a third of patients with CF has given rise to the suggestion that there may be a defect in synthesis of secretory IgA and that the high frequency of allergic manifestations in patients with CF might be due to this defect. ${ }^{24}$ Some support for this has come from the finding of an increased prevalence of precipitating antibodies against gut bacteria. ${ }^{25}$

The most frequent pulmonary pathogens in patients with CF are Staph pyogenes and H influenzae, but as the patients grow older infection with Ps aeruginosa becomes more frequent. This is reflected in the increasing prevalence of precipitating and agglutinating antibodies to these organisms as the patients grow older. ${ }^{26-28}$ In particular, a high proportion of patients who die from CF have pulmonary infection with $P$ s aeruginosa just before death, while a lower proportion of survivors are infected with this organism. ${ }^{18}$ Although infection with Ps aeruginosa is a frequent terminal pulmonary event, it rarely becomes generalised ${ }^{29}$ and most $\mathrm{CF}$ patients' sera show high bactericidal activity against this organism. ${ }^{30} \mathrm{It}$, therefore, seems that CF patients are capable of responding normally in terms of antibody production to infection, and this is borne out by normal responses to influenza vaccine and tetanus toxoid. ${ }^{6}{ }^{19}$

One of the most interesting findings in patients with CF has been the high prevalence of positive skin tests to common allergens, which occur in about $50 \%$ of patients compared to about $10-20 \%$ of the general population. ${ }^{32-36}$ Although the clinical manifestations of allergic aspergillosis have been reported in such patients, ${ }^{37}$ this does not occur as commonly as would be suggested by the frequency of positive skin tests and precipitating antibodies to $A$ fumigatus. ${ }^{38}$ The close relationship between a positive skin test and precipitating antibody in patients with allergic aspergillosis ${ }^{39}$ does not seem to occur in patients with $\mathrm{CF}$, suggesting that the responses of such patients to colonisation of their bronchi by $A$ fumigatus differ from those of other patients. ${ }^{31353638}$ Nevertheless, the presence of evidence of sensitisation to $A$ fumigatus in CF patients is associated with more severe respiratory disease. ${ }^{18}{ }^{34}$ The levels of IgE, both total and specific, are also raised in subjects with CF mainly in relation to positive skin tests. ${ }^{7530-42}$ In spite of all this immunological evidence of atopy, however, the prevalence of clinical manifestations of eczema, rhinitis, and asthma is low, ${ }^{3543}$ though one study has shown a high prevalence of atopy in the parents of children with CF. ${ }^{44}$ Perhaps there is some mucosal abnormality in CF that allows allergens to penetrate and stimulate immunoglobulin production. Secretory IgA may be deficient in atopic patients, ${ }^{\mathbf{4 5}} \mathbf{4 6}$ and if in CF local IgA is functionally deficient this might contribute to the lung damage associated with sensitisation to A fumigatus. Recent work also suggests the presence on the cells of CF patients of the same cytophilic antibody that may be found in patients with allergic aspergillosis, ${ }^{18}{ }^{47}$ and it may be that this antibody is responsible for some of the immunological reactions to $A$ fumigatus in CF.

Other studies of antibodies in patients with CF have produced some other clues as to the tissue damaging mechanisms of the disease. Autoantibodies to pancreas, salivary gland, and lung have $\stackrel{\mathbb{D}}{-}$ been demonstrated in some patients, ${ }^{4-51}$ and there $\vec{\oplus}$ have been conflicting reports of the frequency of antibodies to reticulin. ${ }^{718} \mathrm{~A}$ raised prevalence of anti-smooth muscle antibodies, which may have reflected liver disease, has been reported. ${ }^{18}$ Studies of the complement system have in general shown no consistent abnormalities ${ }^{52-56}$ though some workers $\stackrel{\circ}{\mathcal{D}}$ have reported abnormal levels of $\mathrm{C} 3, \mathrm{C} 4$, and $\mathrm{C} 5,5758 \mathrm{Q}$ particularly in association with infection with Ps aeruginosa. This, in conjunction with the finding of more complement splitting products in the sputum of patients infected with this organism than in those not infected, ${ }^{59}$ has given rise to the suggestion that complement-mediated inflammatory reactions might play a role in the pathogenesis of $\underset{-}{\times}$ pulmonary damage in CF. There is some evidence of 3 immune complex formation in CF, again especially in association with infection with $P$ s aeruginosa and 3 in severely ill patients. ${ }^{60-63}$ Such formation of immune complexes, by activation of complement with subsequent release of enzymes from neutrophils and by inhibition of lymphocytes and alveolar macrophages, may also play some part in the production of pulmo- $\sigma$ nary damage in the disease. Finally, a factor, as yet $N$ uncharacterised, has been found in the serum of patients with $C F$ and of obligatory heterozygotes $\omega$ which inhibits ciliary activity ${ }^{64-66}$ This factor is bound to $\mathrm{IgG}_{1}$ and $\mathrm{IgG}_{2}$ and may be a fragment of C3A with IgG. ${ }^{67} 68$

\section{Polymorphs and macrophages}

The role of polymorphs and macrophages in the $\frac{\widetilde{Q}}{\widetilde{Q}}$ phagocytosis and destruction of bacteria is closely응 related to the functional roles of $\mathbf{T}$ and $\mathbf{B}$ lympho 2 cytes. There is some evidence to suggest that the 
phagocytic activity of rabbit and human alveolar macrophages is reduced in the presence of $\mathrm{CF}$ serum compared to that in normal serum. Conflicting results have been obtained on phagocytosis by polymorphs in the presence of CF serum, though in general this seems to be normal. ${ }^{69-74}$ It seems possible that there may be an opsonising defect in CF serum which causes defective function of alveolar macrophages and this seems worthy of further investigation.

\section{Conclusions}

Patients with CF who die soon after birth from meconium ileus often have anatomically normal lungs, but most patients with CF eventually die under the age of 40 years of overwhelming pulmonary sepsis. Are these patients born with some immunological abnormality which renders them vulnerable to pulmonary infection or are the abnormalities which have been reported the result of long-term infection? A conventional view is that the development of lung disease in CF is the result of excess production of mucus which then gets infected causing pulmonary damage. Some of the features reported such as raised levels of serum immunoglobulins and increased levels of circulating immune complexes are found in other diseases associated with chronic infection. If immunological abnormalities such as high levels of circulating immune complexes are the result of, rather than the initial cause of the disease, they could still contribute to increasing tissue damage. The complexes could attach themselves to receptor sites on macrophages and lymphocytes and interfere with their recognition of bacterial and other antigens. If the immunological abnormalities reported are the result of the disease, then they should not be present in young patients with CF who have not at that time developed severe pulmonary sepsis. Further studies on this group of patients need to be undertaken, and studies which are carried out on adults must in all cases have the immunological features reported in relation to the clinical status of the patients.

It is accepted that the bronchial mucosa of patients with CF produces excessive quantities of mucus which often becomes infected, so it is essential to consider whether some immunological defect may contribute further to the pulmonary damage. An immunological defect could either be generalised or localised to the bronchial tree. Adults with CF have chronic infection at this site, often producing large volumes of purulent sputum, but there does not seem to be an increased incidence of infection at other sites such as skin, gut, urinary tract, or central nervous system. The idea of a local immunological defect within the lung is, therefore, attractive. The advent of the fibreoptic bronchoscope and lavage techniques is now making local studies feasible. Preliminary work indicates that there may be some abnormality of pulmonary alveolar macrophages which is not found among the macrophages of the peripheral blood. If these abnormalities are confirmed, it will again be necessary to ask if the findings are the cause of or the result of the pulmonary sepsis!

Immunological abnormalities contributing to disease tend to be either defective immunological responses or those of hypersensitivity. Defective production of immunoglobulins or defective function of $\mathrm{T}$ cells would predispose an individual to widespread infection. There is no evidence of such deficiencies in CF but there is evidence that there may be a functional defect of local IgA production and this may encourage excess IgE production. On the contrary, there is much evidence of an overactive immune system of CF. A high prevalence of positive type 1 skin test reactions to common allergens and $A$ fumigatus together with type 3 responses in skin and serum to $A$ fumigatus have been reported though again it is possible that these findings may be the result of the disease process. Most patients with CF have malabsorption and it is possible that the mucosal defect allows food and bacterial antigens to be absorbed and to sensitise the patient, leading to excess IgE production. Patients with $\mathrm{CF}$ are indeed exposed to more bacterial and pharmaceutical antigens than are fit individuals. It is an unconventional but intriguing explanation that the IgE producing cells may be stimulated as an amplification system to back up the protective role of IgA when the respiratory tract is challenged with many bacterial antigens as it is in these patients with severe lung infection. Such a theory would explain the high prevalence of immediate type 1 skin test responses to common allergens and the various immunological responses to $A$ fumigatus. In classical bronchopulmonary aspergillosis type 1 and type 3 skin tests and serum precipitins are found. However, in CF some patients have precipitins without positive skin test reactions. If the antigen has access through the abnormal mucosal surface of the gut in cystic fibrosis this may cause circulating antibody to be produced without classical skin sensitisation. In allergic bronchopulmonary aspergillosis type 3 reactions to $A$ fumigatus are known to be tissue damaging. It may be that the initial damage to the lung in CF is caused by bacterial infection, but that once infection is established then the lung damage becomes progressively worse as the result of cell-mediated immune reactions to both bacterial and fungal antigens. 
These features together with increased levels of circulating immunoglobulins and the finding of autoantibodies in the serum of these patients must stimulate interest in the T cell subpopulations in CF. No work has yet been published on this aspect of the immune response in CF but it needs urgent exploration. If there is some imbalance between suppressor $T$ and helper $T$ cell activity in this disease, this could account for many of the immunological features reported. If this imbalance results in an overactive immune response which is itself causing damage to the already infected lung of the patient with $\mathrm{CF}$, the logical conclusion might be that patients with CF should be treated with steroids or immunosuppressive agents early in life before abnormal immune responses can cause tissue damage. These methods of treatment would however be totally unacceptable without much stronger supporting evidence.

MARGARET E HODSON
Cardiothoracic Institute
Brompton Hospital
London

\section{References}

1 Andersen DH. Cystic fibrosis of the pancreas and its relation to celiac disease: a clinical and pathological study. Am J Dis Child 1938; 56:344-99.

2 di Sant'agnese PA, Davis PB. Cystic fibrosis in adults. Am J Med 1979; 66:121-32.

3 Shwachman H, Kowalski M, Khaw KT. Cystic fibrosis: a new outlook. Medicine 1977; 56:129-49.

4 Mitchell-Heggs P, Mearns M, Batten JC. Cystic fibrosis in adolescents and adults. $Q J$ Med 1976; 45:479-504.

5 Hoiby N, Mathiesen K. Pseudomonas aeruginosa infection in cystic fibrosis. Distribution of $\mathrm{B}$ and $\mathrm{T}$ lymphocytes in relation to the humoral immune response. Acta Pathol Microbiol Scand (B) 1974; 82:559-66.

6 Saint Remy JM, Plowman N, Vick R, Cole P, Hodson ME, Batten JC. Immunological aspects of cystic fibrosis (in preparation).

7 Wallwork JC, Brenchley P, McCarthy J et al. Some aspects of immunity in patients with cystic fibrosis. Clin Exp Immunol 1974; 18:303-20.

8 Marchi AG, Marchi MA, Mastella G, Nordio S. Abnormal beta-glucuronidase activity in cystic fibrosis. Helv Paediatr Acta 1973; 28:427-35.

9 Lieberman J, Kaneshiro W. Abnormal response of cultured lymphocytes to phytohemagglutinin and autologous serum in cystic fibrosis. Am Rev Respir Dis 1977; 116:1047-55.

10 Sorensen RU, Stern RC, Polmar SH. Lymphocyte responsiveness to Pseudomonas aeruginosa in cystic fibrosis. Relationship to status of pulmonary disease in sibling pairs. J Pediatr 1978; 93:201-5.

11 Gibbons A, Allan JD, Holzel A, McFarlane H.
Cell-mediated immunity in patients with cystic fibrosis. $\mathrm{Br}$ Med J 1976; 1:120-2.

12 Talamo RL, Stiehm ER, Schwartz RH. Immunological aspects of cystic fibrosis. In: Mangos JA, Talamo RC, eds. Cystic fibrosis: projections into the is future. New York: Stratton, 1976.

13 Green MN, Kilczycki LL, Shwachman H. Serum protein paper electrophoresis in patients with cystic fibrosis. Am J Dis Child 1960; 100:365-72.

14 Schwartz RH. Serum immunoglobulin levels in $\vec{x}$ cystic fibrosis. Am J Dis Child 1966; $111: 408-11$.

15 Marcer V, Mastella G, Mengoli V. Immunoglobulins o in serum, sputum and saliva in patients affected with $\vec{\longrightarrow}$ cystic fibrosis (mucoviscidosis) and important oo respiratory complications. Riv Clin Pediatr 1970; 오 83:135-43.

16 Yohe RM. Allergy in patients with cystic fibrosis. Ann Allergy 1972; 30:627-31.

17 Collins-Williams C, Thachyk SJ, Toft B, Generoso L, Moscarello M. Quantitative immunoglobulin levels (IgG, IgA and IgM) in children with intractable asthma. Ann Allergy 1967; 25:177-82.

18 Hodson ME. MD Thesis. Immunological features of cystic fibrosis. Leeds, 1977.

19 Matthews WJ, Williams M, Oliphint B, Geha R, Colten HR. Hypogammaglobulinemia in patients with cystic fibrosis. $N$ Eng J Med 1980; 302:245-9.

20 South MA, Warwick WJ, Wollheim FA, Good PA. The IgA system 3, IgA levels in the serum of saliva of pediatric patients-evidence for local immuno- $\frac{\circ}{\mathbb{D}}$ logical system. J Pediatr 1967; 71:645-53.

21 Gugler E, Pallavicini JC, Swerdlow H, Zipkin I, $\overline{\bar{o}}$ di Sant'agnese PA. Immunological studies of sub- 3 maxillary saliva from patients with cystic fibrosis and from normal children. J Pediatr 1968; 73:548-59.

22 Martinez-Tello FJ, Braun DG, Blanc WA. Immunoglobulin production in bronchial mucosa and $\overline{0}$ bronchial lymph nodes, particular in cystic fibrosis of the pancreas. J Immunol 1968; $101: 989-1003$.

23 Falchuk ZM, Taussig LM. IgA synthesis by jejunal biopsies from patients with cystic fibrosis and hereditary pancreatitis. Pediatrics 1973; $51: 49-59$.

24 Wallwork JC, McFarlane H. The SIgA system and hypersensitivity in patients with cystic fibrosis. Clin 욱 Allergy 1976; 6:349-58.

25 Hoiby N, Hertz JB. Precipitating antibodies against E.coli, B.fragilis and P.aeruginisa in CF patients and normal persons determined by means of crossed of immunoelectrophoresis. Monogr Paediatr 1979; N 10:138-43.

26 May JR, Herrick NC, Thompson D. Bacterial $\mathbb{N}^{\circ}$ infection in cystic fibrosis. Arch Dis Child 1972; 47:908-13.

27 Høiby N. Pseudomonas aeruginosa infection in $\frac{\widetilde{\Phi}}{\Phi}$ cystic fibrosis. Diagnostic and prognostic significance $\stackrel{\mathscr{P}}{+}$ of Pseudomonas aeruginosa precipitins determined 0 by means of crossed immunoelectrophoresis. A survey. Acta Path Microbiol Scand (C) 1977; Suppl $\underset{\mathbb{D}}{ }$ 262:3-96.

28 Habboushe C, Iacocca V, Braddock L, Barbero G. $\stackrel{\mathbb{2}}{\varrho}$ Pseudomonas agglutinins in patients with cystic fibrosis. Pediatrics 1971; 48:973-4. 
29 Wood RE, Boat TF, Doershuk CF. Cystic fibrosis. Am Rev Respir Dis 1976; 113:833-78.

30 Høiby N, Olling S. Pseudomonas aeruginosa infection in cystic fibrosis. Acta Path Microbiol Scand (C) 1977; 85:107-14.

31 McCarthy DS, Pepys J, Batten JC. Hypersensitivity to fungi in cystic fibrosis. In: Lawson $D$, ed. Proceedings of the Fifth International Cystic Fibrosis Conference, Cambridge. London: Cystic Fibrosis Trust, 1969; 194-204.

32 Kulczycki LL, Mueller H, Shwachman H. Respiratory allergy in patients with cystic fibrosis. JAMA $1961 ; 175: 358-64$.

33 Van Metre TE, Cooke RE, Gibson LE, Winkenwerder WL. Evidence of allergy in patients with cystic fibrosis in the pancreas. J. Allergy 1960; 31:141-50.

34 Warner JO, Taylor BW, Norman AP, Soothill JF. Association of cystic fibrosis with allergy. Arch Dis Child 1976; 51:507-11.

35 Warren CPW, Tai E, Batten JC, Hutchcroft BJ, Pepys J. Cystic fibrosis: immunological reactions to Aspergillus fumigatus and common allergens. Clin Allergy 1975; 5:1-12.

36 Nelson LA, Callerame ML, Schwartz RH. Aspergillosis and atopy in cystic fibrosis. Am Rev Respir Dis 1979; 120:863-73.

37 Mearns MB, Young W, Batten JC. Transient pulmonary infiltrations in cystic fibrosis due to allergic aspergillosis. Thorax 1965; 20:385-92.

38 Mearns MB, Longbottom J, Batten JC. Precipitating antibodies to Aspergillus fumigatus in cystic fibrosis. Lancet 1967; 1:538-9.

39 McCarthy DS, Pepys J. Allergic bronchopulmonary aspergillosis. Clinical Immunology (2) Skin, nasal and bronchial tests. Clin Allergy 1971; 1:415-32.

40 Rachelefsky GS, Osher A, Dooley RE, Ank B, Stiehm ER. Coexistent respiratory allergy and cystic fibrosis. Am J Dis Child 1974; 128:355-9.

41 Allan JD, Moss AD, Wallwork JC, McFarlane H. Immediate hypersensitivity in patients with cystic fibrosis. Clin Allergy 1975; 5:255-61.

42 McFarlane H, Allan JD, Van der Zeil P. Passive cutaneous anaphylaxis and specific IgE in cystic fibrosis and their heterozygotes. Clin Allergy 1977; 7:279-84.

43 Counahan R, Mearns MB. Prevalence of atopy and exercise-induced bronchial lability in relatives of patients with cystic fibrosis. Arch Dis Child 1975; 50:477-81.

44 Warner JO, Norman AP, Soothill JF. Cystic fibrosis heterozygosity in the pathogenesis of allergy. Lancet 1976; 1:990-1.

45 Taylor B, Norman AP, Orgel HA, Stokes CR, Turner MW, Soothill JF. Transient IgA deficiency in pathogenesis of infantile atopy. Lancet 1973; 2:111-3.

46 Salvaggio JE, Waldman RH, Frutchman $\mathrm{MH}$, Wigley FM, Johnson JE. Specific and secretory antibody response of atopic and nonatopic individuals to intransally administered tetanus toxoid. Clin Allergy 1973; 3:43-9.
47 Assem ESK, Turner-Warwick M. Cytophilic antibodies in bronchopulmonary aspergilloma and cryptogenic pulmonary eosinophilia. Clin Exp Immunol 1976; 26:67-77.

48 Murray MJ, Thal AP. The clinical significance of circulating pancreatic antibodies. Ann Intern Med $1960 ; 53: 548-55$.

49 Blanc WA. Immunocytological techniques in cystic fibrosis of the pancreas. In: di Sant'agnese PA, ed. Proceedings of the Third International Conference on Research on Pathogenesis of Cystic Fibrosis of the Pancreas. Lancaster, Pennsylvania: Wickersham Printing, 1964; 327-38.

50 Patterson PR. Specific Iso-antibodies in cystic fibrosis. In: di Sant'agnese PA, ed. Proceedings of the Third International Congress of Research on Pathogenesis of Cystic Fibrosis of the Pancreas. Lancaster, Pennsylvania: Wickersham Printing, $1964 ; 317-26$.

51 Stein AA, Manlapas FC, Soike KF, Patterson PA. Specific Iso-antibodies in cystic fibrosis. A study of serum and bronchial mucus. J Pediatr 1964; 65:495-500.

52 Conover JH, Conod EJ, Hirschhorn K. Complement components in cystic fibrosis. Lancet 1973; 2:1501.

53 Lieberman J. Carboxypeptidase B-like activity and C3 in cystic fibrosis. Am Rev Respir Dis 1975; 111:100-2.

54 Scanlin TF, Norman ME, Rosenlund ML. C3 in cystic fibrosis. Lancet $1975 ; 1: 1382$.

55 Buescher ES, Winkelstein JA. The ability of bacteria to activate the terminal complement components in serum of patients with cystic fibrosis. J Pediatr 1978; 93:530-1.

56 Lyrene RK, Polhill RB, Guthrie LA, Tiller RE. Alternative complement pathway activity in cystic fibrosis. J Pediatr 1977; 91:681-2.

57 Hann S, Holsclaw OS, Shin HS. Complement components in cystic fibrosis. Lancet 1974; $2: 520-1$.

58 Gotz M, Lubec G. Complement in cystic fibrosis. Eur J Pediatr 1978; 127:133-9.

59 Schiøtz PO, Sørensen H, Høiby N. Complement activation and pulmonary inflammation in cystic fibrosis patients. Monogr Paediatr 1979; 10:131-4.

60 McFarlane H, Holzel A, Brenchley P et al. Immune complexes in cystic fibrosis. $\mathrm{Br}$ Med $J$ 1975; 1:423-8.

61 Schiøtz PO, Nielsen N, Høiby N, Glikmann G, Svehag SE. Immune complexes in the sputum of patients with cystic fibrosis suffering from chronic pseudomonas aeruginosa lung infection. Acta Pathol Microbiol Scand $(C)$ 1978; 86:37-40.

62 Beldon I, Hodson ME, Batten JC. Circulating immune complexes in the sera of patients with cystic fibrosis. Proceedings of the Eighth International Congress in Cystic Fibrosis. Toronto Canada 1980.

63 Schiøtz PO, Høiby N, Juhl F, Permin H, Nielsen H, Svehag SE. Immune complexes in cystic fibrosis. Acta Pathol Micriobiol Scand (C) 1977; 85:57-64.

64 Spock A, Heick HM, Crass H, Logan WS. Abnormal serum factor in patients with cystic fibrosis. 
Paediatr Res 1967; 1:173-7.

65 Besley GT, Patrick AD, Norman AP. Inhibition of the motility of gill cilia of Dreissensia by plasma of cystic fibrosis in patients and their parents. $J$ Med Genet 1969; 6:278-80.

66 Bowman BH, Lockhart LH, McCombs ML. Oyster ciliary inhibition by cystic fibrosis factor. Science $1969 ; 164: 325-6$.

67 Danes BS, Litwin SD, Hütteroth TH, Cleve H, Bearn AG. Characterization of cystic fibrosis factor and its interaction with human immunoglobulin. $J$ Exp Med 1973; 137:1538-43.

68 Conover JH, Conod EJ, Hirschhorn K. Studies on ciliary dyskinesia factor in cystic fibrosis. Life Sci $1974 ; 14: 253-66$.

69 Bigger WD, Holmes B, Good RA. Opsonic defects in patients with cystic fibrosis of the pancreas. Proc Natl Acad Sci USA 1971; 68:1716-9.
70 Boxerbaum B, Kagumba M, Matthews LW. Selective inhibition of phagocytic activity of rabbit $\frac{\omega}{2}$ alveolar macrophages in cystic fibrosis serum. $A m \mathbb{\otimes}$ Rev Respir Dis 1973; 108:777-83.

71 Böhme B. Phagozytosedefekt der granulozyten bei $\stackrel{\text { के }}{\text { D }}$ zystischer fibrose. HelvPaediatr Acta 1972;27:607-12. $\vec{\circ}$

72 Böhme B. Untersuchungen zur zellulären Abwehr gegen Pseudomonas aeruginosa bei Mukoviszidose. Z Erkr Atm 1975; 143:66-9.

73 Church JA, Keens TG, Wang CI, O'Neal M, 氶 Richards W. Normal neutrophil and monocyte chemotaxis in patients with cystic fibrosis. $J$ Pediatr 1979; 95:272-4.

74 Cole P, Williams A, Roberts D, Knight R, Hodson ME, Batten JC. Pulmonary and peripheral blood phagocyte function in cystic fibrosis. Proceedings of $\mathrm{O}$ the Eighth International Congress on Cystic Fibrosis. Toronto Canada 1980. 